\title{
Article
}

\section{Repairing Political Trust for Practical Sustainability}

\author{
Robert Weymouth *, Janette Hartz-Karp and Dora Marinova \\ Curtin University Sustainability Policy (CUSP) Institute, Curtin University, Perth 6102, Australia; \\ J.Hartz-Karp@curtin.edu.au (J.H.-K.); D.Marinova@curtin.edu.au (D.M.) \\ * Correspondence: robert.weymouth@postgrad.curtin.edu.au
}

Received: 20 July 2020; Accepted: 27 August 2020; Published: 29 August 2020

check for updates

\begin{abstract}
High levels of trust in government are important in addressing complex issues, including the realization of the mainstream sustainability agenda. However, trust in government has been declining for decades across the western world, undermining legitimacy and hampering policy implementation and planning for long-term sustainability. We hypothesize that an important factor in this decline is citizen disappointment with the current types of public participation in governance and that this could be reversed through a change from informing/consulting to a relationship of partnership. Using case studies from Western Australia, the paper investigates whether an intervention targeted at establishing a partnership relationship through mini-public, deliberative, participatory budgeting would improve trust and help the implementation of sustainability. These results show evidence of improvements in trust and provide conceptual and practical tools for government administrations wishing to close the detrimental trust gap that may hamper the implementation of a sustainability agenda.
\end{abstract}

Keywords: sustainable development; goals; sustainability; deliberative democracy; public participation; political trust; government; mini-public; participatory budgeting; Australia

\section{Introduction}

Some of the most interesting questions in the study of sustainable development today concern the practical implementation of the sustainability agenda. What is often presumed within implementation, but not directly addressed, particularly by governments, is the important role of political trust in the real-world achievement of sustainability. Low trust levels can be a significant impediment to action on current sustainability challenges, and a source of future uncertainty that could undermine any achievements or endanger further progress.

The goal of this article is to provide guidance for governments wishing to build political trust when making decisions, either for the implementation of sustainability initiatives or within their wider governance. It outlines principles and processes that could potentially also be used to build political trust during the stage of developing broad understanding of the meaning of sustainability, its values, and priorities. We hypothesize that changing the form of citizens' public participation in governance to one of partnerships will improve political trust levels and the likelihood of implementing sustainability initiatives.

This hypothesis is approached with a blend of inductive and abductive reasoning. We explore the phenomena of political trust, sustainability, and participation to test and adjust existing theories and arrive at a plausible explanation rather than a deductively perfect one. This is an accepted approach given the complexity of the field and the difficulty in establishing causation $[1,2]$. Specifically, we first examine the literature to ascertain the link between public participation and trust and deduce the intervention type most likely to increase trust. We then use mixed-methods case studies to analyze the effectiveness of the intervention predicted to change the relationship between political actors and citizens and increase trust. Accordingly, this article is organized into three parts: 
1. An overview and synthesis of the literature on political trust and its relationship to citizens' participative relationship with government. This gives grounds for proposing an intervention that could test our hypothesis.

2. An examination of this intervention via two case studies involving $100 \%$ participatory budgeting through deliberative democracy initiatives aimed at developing more sustainable budgeting, to see whether the results support our hypothesis.

3. A discussion of the implications of the results for political trust and sustainability implementation.

Before embarking on the main analysis in the paper, it is appropriate to establish our framing and definition of trust. Although there are diverse definitions and determinants of trust, all agree that this is a perception affected by a multitude of psychological and other factors [3,4]. Though the precise definitions of trust may vary, we concur with the cross-disciplinary consensus of it as: " . . the willingness to be vulnerable under conditions of risk and interdependence ... " [3] with positive expectations of the other party's intentions and behavior. This willingness manifests as: “. . a psychological state or orientation of an actor (the truster) toward a specific partner (the trustee) with whom the actor is in some way interdependent (that is, the truster needs the trustee's cooperation to attain valued outcomes or resources)" [4]. We also note that trust is by definition distinct and separable from distrust-its mirror image opposite concerning the expectation that there will be negative intentions and behavior toward the trustee.

Of the many influencers of trust [5-7], we focus on two important to balance granularity of understanding, parsimony of variables, and validity of measurement. The first we call "competence," which is a belief in the ability of the trustee to contribute to the outcomes that the truster requires; the second is described as "benevolence," which is an assessment that the motivation of the trustee is to act in the truster interests. Previous research has found a clean separation between variables describing competence or performance and variables that describe benevolence or integrity [7]. The absence of either undermines trust-either party may be well-intentioned but unable to perform or they may be competent but unreliable or lacking integrity. In either case, less than full trust will be present. This dual focus has been used in various fields [5], including education [8], public sector management [6], interpersonal trust [4,9] and software utilization [10]. By integrating these two drivers, we define trust as: A person's judgement that another interdependent person or body has both the benevolence and competence to act in their interest in matters of importance.

We can extend this definition to help understand political trust since it is a subset of generalized social trust [11,12]. Hence, political trust is a citizens' belief in the benevolence or intention of political actors to work in their collective best interests, and the capacity, ability, or competence of those actors to achieve some expected governance outcome. These political actors may be individual politicians or the collective institutions of government depending on the context. The governance outcome may be a level of service provision or meeting a particular norm, such as transparency or representation. This definition is congruent with the general understanding of trust, and mirrors elements of political trust described by other authors [5,13-17]. The value of this definition is independently supported by modelling [18], the analysis of large data sets [19-23], and it helps guide the exploration to follow.

\section{Literature Review}

Having established a conceptual understanding, we now review the state of political trust in government globally. This is followed by an overview of the link between public participation and trust in search of interventions that can improve such a relationship.

\subsection{Do Citizens Trust Government?}

There is plentiful data from the last couple of decades on the public's generalized trust in political actors and the evidence is not reassuring. It is generally (although not universally) agreed that over the last 30 years there has been a long-term decline in citizen trust in government in mature democracies [24]. The best data set is from the US which shows that over 44 years, political trust has 
dropped from $78 \%$ to $44 \%$ [25,26] with increasingly apparent negative impacts [27-30]. Lack of political trust has been shown to undermine public engagement, hamper long-term policy, and hinder collective action [31,32]. On the other hand, increases in trust ameliorate these effects and boost support for unpopular government services and initiatives [33-35].

Utilizing our definition of political trust, the sources of the decline can be framed as either a failure of government to meet citizens' competence expectations, or a failure by government to demonstrate it is acting in the best interests of the citizenry, or both. Previous research has provided examples and clarified these trust-degrading factors. Perceived failure to perform to citizens' competency expectations [29] partially drove the public administration performance movement at the turn of the millennium [26,36], but did not interrupt the downward trend in trust [11]. Evidence from government interactions from around the same period also showed that the actual process is at least as important as performance for trust and legitimacy - even when the outcomes of the process go against individual self-interest $[27,37,38]$. Such an analysis confirmed that the presence of a government process is a strong signal of respect [39] and indicative of how citizen-centric its intentions are at both country and individual levels. The effect of process was found to be larger than that of performance in determining the trustworthiness of public servants and the two factors are not separable, with good processes tending to produce good outcomes and vice-versa [26]. Adding to this, perceived motivations and benevolence are integral to citizens' normative expectations of government [40], and citizens in many countries believe governments are failing to represent their collective will [41,42].

The decline of political trust appears to be widespread and there is good evidence to support its conceptualization as perceptions of political actors' lack of benevolence toward citizens and/or lack of competency in terms of actions and processes. Given the importance of trust to addressing many of the problems that confront development, finding a way to redress its deficit is a priority for governments which have committed to goals, such as sustainability. Although there are genetic, developmental, cognitive, and affective [4,43] factors that influence any person's trust decision, these are all outside the direct influence of governments or policy actors. However, public participation in governance is one of the few ways government can influence political trust and this is examined below.

\subsection{Public Participation as a Way of Building Political Trust}

In the literature "public participation" describes the involvement of stakeholders in policies, programs, and plans of governments [44]. Since citizens are important stakeholders in this process in a democracy, their involvement- "citizen participation," shapes the nature of the relationship that citizens have with the decisions of their democratic governments. The type of relationship formed depends on the actions that government officials take to engage with citizens, and that citizens take to influence government actions and decisions [44]. Citizen actions may be formalized, e.g., membership of a political party, attending a consultation, or voting, or not, e.g., public demonstrations or contributing to internet discussion forums [45].

There is strong prima facie evidence for the presumption that citizen participation in democracy is important to political trust. Normatively, this type of participation is intrinsic to the nature and performance of democracy [46,47]; so deficits in citizen participation are shortcomings of this ideal. What is more strongly contested is the type and degree of participation that citizens expect and desire from their government. It has been contended that citizens are mostly disinterested or conflicted regarding participation, and only engage through fear of loss and corruption [40,48]. However, more recently the weight of evidence has shifted against this, with data being re-interpreted as frustration with the existing participation modes and general lack of political participation [49-52]. Further empirical work has confirmed the importance of participation for political trust [53], with civic engagement factors having twice higher effect on trust than government performance factors $[11,20]$. However, results are highly dependent on the participation design and whether the focus is on the collective, individual, outcome, or process [51,54]. 
Thus, given the link between participation and trust in government, it is important to ask: What type of participation do citizens expect, and are governments living up to this expectation? Recent research in Australia and the US [55,56] using the tool of a modified Arnstein ladder [55,57,58] (see Figure 1) found a difference between the level of participation that citizens would ideally like and that which is being provided to them—known as the Arnstein gap [59].

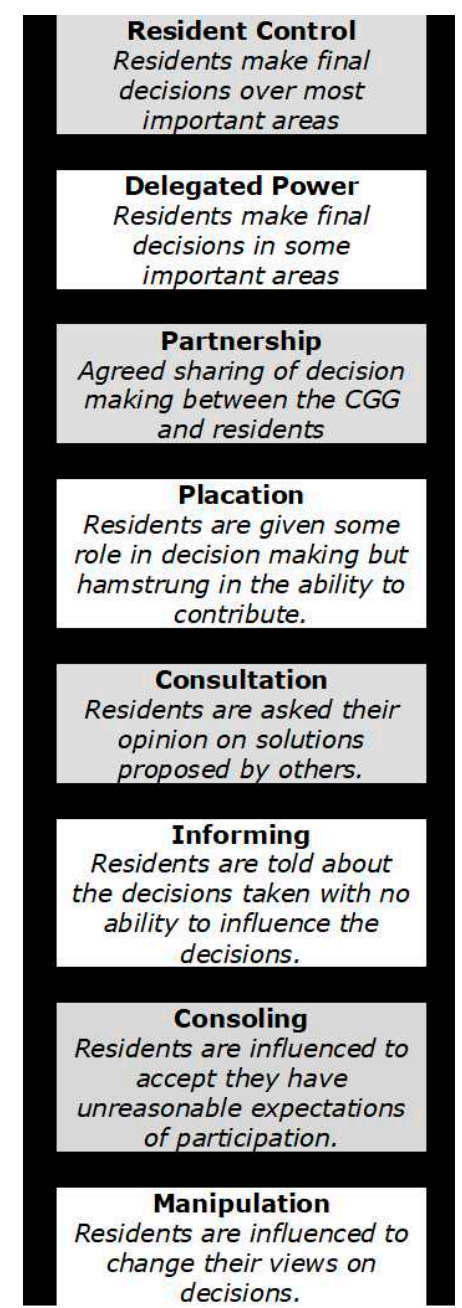

Figure 1. Modified Arnstein ladder referencing City of Greater Geraldton-CGG (with permission [55]).

On average, citizens wish to have a relationship with government characterized as "partnership" on the Arnstein ladder. Instead, they experience "consultation" or "informing," several levels lower on the ladder. This performance/expectation gap was detected in government officials as well as the general public in case studies in the US and Australia [55]. These results overlap with other authors who have found sometimes contradictory preferences for participation in surveys that force dichotomous choices on participants between pure citizen or pure technocratic government control [50,60-62]. Our interpretation is that such framing overly focuses on extremes of direct or representative democracy, which misses the partnership preferred by citizens in most mature democracies. The existing informing/consultation relationship [63] often creates unsatisfactory outcomes, disengagement and barriers to government action [38,64-67], disengagement [51], reduced voting [68], and disgruntled attitudes toward government [69].

Such dissatisfaction and inability to meet citizen expectations degrade trust in government. Limiting the design and planning of solutions to bureaucrats, interest groups, and lobbyists [70] does not always produce holistic results and often creates an impression of government captured 
by special interests or manipulating the public to do what is "best" for them [71,72]. Not only do perceptions of competence suffer but also the view of government acting in the public interest or benevolence [6,73]. When failures to solve problems and perceptions of not acting in the public's good repeat over multiple issues and years, affective lack of trust will grow [74] and cognitive biases $[75,76]$ can become self-reinforcing $[4,37,77,78]$.

In addition to having a good understanding of citizens' dissatisfaction with the status quo, there is also evidence that it is possible to meet expectations and close the Arnstein gap. Previous research on the case studies used later in this article analyzed a deliberative democracy intervention [79] aimed specifically at increasing the public participation level to "partnership" [55]. The Arnstein gap between expectation and reality closed by two-thirds in response to this intervention. Furthermore, the qualitative investigation revealed that by selecting "partnership," citizens wished for political equality, where each side respected the other's strengths and skills whilst working toward a common goal. This political equality was realized through the modes of speech but also the sharing of power and decision-making [55]. It also highlighted how citizens and government officials assessed whether they were in "partnership." For the citizens, this centered on whether the government representatives were competent in their domain (in this instance, budgetary allocation in subject areas) and whether they were acting in the best interests of the community. The government officials used two analogous but slightly different criteria. They judged the citizens by their competence as deliberative thinkers (rather than subject matter experts), but also by their community orientation (whether they were representing the wider community) [55]. This latter form of 'benevolence' - the citizens collectively acted for the benefit of the whole community rather than representing their narrow interests-was primarily determined by the officials through examining their decisions and justifications. The competency of deliberating on budgets was assessed through observation of both process and the justifications of the citizen decision-making. These themes of competence and benevolence are strikingly similar to the criteria used to judge trust. In our view, this is no coincidence. The partnership relationship on the Arnstein ladder requires interdependence and mutual trust more than any of the other levels and hence the components of trust occupy such prominence in this relationship. In comparison, at lower levels, citizens are disempowered, so it is not necessary to vest any trust in them; equally at higher levels, citizens hold disproportionate power, and only require the machinery of government to implement their decisions.

So far, we have shown that the literature supports a relationship between public participation and political trust. Now we can specify the details of an intervention that can change the relationship between political actors and citizens to one characterized as "partnership" to effectively improve trust.

\subsection{Interventions That Could Improve Trust in Government}

Our hypothesis is that a form of intervention exists that can meet citizens' expectations of partnership, and can increase political trust [80]. This is not just based on citizen preferences from surveys, but also two additional lines of evidence. Firstly, there is evidence of a connection between trust and elements of partnership that signal benevolence. Political trust in government has been linked to process elements, such as the openness of government institutions [53], the perception of fairness [15,81], and the use of more deliberative and participative techniques [44,81,82]. As Christensen concludes: "Citizens who are integrated, involved, and engaged in the political system generally have a significantly higher level of trust in most governmental institutions than people who are less integrated, less involved, and less engaged" [20]. Secondly, there is solid support for links between trust and elements of partnership that increase perceived competence. Several authors have argued for and demonstrated that a relationship where citizens and government bring their informational perspectives to a complex problem in a more equal manner creates epistemically superior outcomes [83-86]. More specifically, research has shown that using partnership relationships in problems where there is a plurality of conflicting values improves the perceived competency and legitimacy of the outcomes $[64,87-89]$. These assumptions 
hold when there is no path dependency or "lock-in" in the system which is a topic requiring further research [80].

Having established that a partnership intervention is likely to succeed in most common cases, we now move to how it could actually be operationalized in a case study. From our definition of political trust, the relationship would have to be characterized by relative power equality, a focus on performance and outcomes, a necessary and significant contribution by both parties, and commitment to a common goal that is consequential and important. These criteria closely match the characteristics and practice of deliberative democracy. Deliberative democracy focusses on creating egalitarian spaces for deliberation between citizens who represent/mirror the broader population, to resolve issues of importance, with the outcomes influencing policy development or decision-making [90,91]. Deliberation ideally promotes respectful communication, using justification and reflection to work toward possible consensus or common ground. It has a stronger partnership focus than other modes of democratic governance [84,92].

This contrasts with other possible democratic interventions. For example, participative democracy does not necessarily speak to the level of participation or influence, and could be classified as operating at almost all but the lowest levels of the Arnstein ladder [93]. Direct democracy "overshoots" the partnership level by preferring delegation or citizen control which requires much less trust. Representative democracy focuses on the creation of representatives of the citizenry through voting in which citizens notionally have equal power, but only at the time of their vote for the selection of representatives. In modern societies this leads to a series of principal-agent relationships that do not always function as expected $[17,94]$. The aggregative nature of a single vote every few years rarely connects up to the public policy cycle, diluting equality, and shifting power to economic elites [95], elected members, and non-elected officials [96]. As discussed in the section on participation, Arnstein surveys reinforce the evidence about failure of the current representative system to realize partnership with citizens, instead, rating the government's relationship with them as informing or consulting [55].

While there is evidence of a direct association between trust and deliberation generally [97-99], the strongest arguments for this link focus on a particular implementation of deliberative democracy that embodies the partnership relationship-mini-publics. A mini-public [100] involves a group of citizens who are descriptively representative, i.e., randomly selected from the population, and usually stratified to represent important demographic characteristics, such as gender, age, or socio-economic status. These citizens typically engage in small-group discussions on a topic of importance, with deliberation assisted by an independent facilitator using a range of deliberative technologies [101], and aim to reach collective positions or recommendations [102]. The characteristics of deliberative mini-publics uniquely facilitate partnership. Random selection, facilitation, and the search for common ground tend to prevent group polarization and cognitive errors that undermine competent decision-making $[84,99,103,104]$. Selecting diverse but non-invested citizens also increases the chance of the group acting benevolently and forming a common will $[105,106]$, rather than leaning towards partisan or narrow ends. Such citizens are less subject to the trust degrading influences in the existing system, and tend to be more moderate and willing to trust than professional politicians [13].

Hence, in terms of finding an effective intervention in the governance cycle to promote partnership and address the declines in political trust, deliberative democracy mini-publics are strong contenders. Such an intervention is applied in the two case studies described below.

\section{Methods}

In the service of testing our hypothesis, we describe the details of the case studies examined and justify the used intervention. We also outline the methods we used to measure the important variables that allow us to draw conclusions about the validity of the developed hypothesis. 


\subsection{Case Study Details}

The case studies took place in the local government area of the City of Greater Geraldton (referred to as Geraldton) in Western Australia, dominated by the regional center of Geraldton containing around 35,000 people. From 2010 to 2014, a deliberative democracy program was run that included multiple collaborative governance events [107] and culminated in two Australian participatory budgeting initiatives covering $100 \%$ of the local government budget [108]. Participatory budgeting (PB) is a democratic process which directly involves citizens in setting part, in our cases all, of a government budget. Over the last three decades, this format has spread from South America, where it originated, to all over the world. It has been adopted predominantly by local governments [109] which have developed distinct regional patterns of execution $[110,111]$. The most common style of PB has citizen groups developing options for a part of a budget and a wider public voting to prioritize those options. This budget is then spent according to these priorities. The levels of deliberativeness in the process vary depending on the style and region. The "Australian-style" PB typically addresses 100\% of a city/region's budget and is executed through the use of deliberative democratic mini-publics. This contrasts with the majority of the PBs to this date which are on the lower end of the deliberative scale and usually only deal with $5 \%$ of a larger budget $[112,113]$. Since the Geraldton PBs rate very highly as deliberative democracy initiatives (see Section 4.1), from this point forward we will refer to these deliberative democracy interventions as the "PBs." This was how the participants understood the process they were selected for and participated in.

Comprehensive details of the Greater Geraldton PBs have been previously documented [108]. In short, two separate mini-publics of between 30 to 40 citizens were drawn by stratified random sampling by independent demographers to ensure descriptive representation of the region's population [114]. The first mini-public was executed in November 2013. Its task was to prioritize over AUD70 million of infrastructure spending for the next decade. Called the "Capital Works Panel," the mini-public panelists met for four and a half consecutive Saturdays to discuss and rate 130 infrastructure projects using a deliberative form of a multi-criteria analysis technique. The second mini-public met for eight consecutive Saturdays to allocate the local government's AUD70 million operational budget for the coming financial year. Called the "Range and Level of Services Panel" or the "Operations PB," panelists made recommendations on whether service areas should be increased, decreased, or held constant, when assessed according to a values-based process [87].

\subsection{Case Study Suitability}

These two PBs are useful case studies to analyze political trust in the first instance because Australian governments, like many democracies today, are experiencing longitudinal declines in political trust [32] - a worrying trend coupled with surveys showing only about $30 \%$ of citizens currently trust the national government [115]. Such lack of trust is specifically focused on most political actors in government with other parts of the executive system, such as law enforcement, not affected to the same degree [116]. Citizens were specifically skeptical of government performance on complex problems, and it seemed to be starting to join a worldwide move toward greater dissatisfaction with the idea of democracy itself [117]. There was also evidence of a belief amongst Australian citizens that governments were not acting in the interests of the greater good [34]. The problem was not confined to the federal level, with only half of the citizens trusting the state government [118] and around the same for local government [119]. In these particular case studies, trust in the local government was probably at a low ebb because of public reaction to large rate rises by the City of Greater Geraldton [120]. This loss of trust was ironically created by attempts by the Greater Geraldton local government to improve the financial aspect of its sustainability, partially in response to incurring infrastructure deficits [121] and funding sustainability services requested by the community [122]. Overall then, the case studies were likely to provide a valid test of a government/citizen trust dynamic that is negative and widely applicable to many democracies. 
The case studies are also useful because they allow to test an intervention that authentically embodies citizens' preferred relationship with government-that of partnership, which Australians reaffirm as their ideal $[34,55,123]$. On the face of it, PBs seem well-suited to achieve a competent power sharing for the common good. Their intrinsic concern with concrete matters of money and finance results in tangible outcomes with real influence. The cyclical nature of budgets also makes them appropriate for the creation of virtuous cycles $[124,125]$, unlike the oft-heard critique of mini-publics, that they are isolated and opportunistic [126,127].

There is some preliminary evidence from US participatory budgeting events that showed statistically significant improvements in political trust between telephone, online, and face-to-face deliberative modes of participation [82,128]. However, many PBs do not realize the full potential for a partnering relationship with political actors through inadequate framing, incomplete deliberation, insufficient power sharing, or lack of repetition. Such "consultational" PBs may leave final allocations to officials, use uninformed opinion-based allocation, or allocate insignificant fractions of expenditure [129]. This can eliminate any trust gains by citizens [130], but also lead to government officials assessing citizens as lacking competence [131].

In the two Greater Geraldton-based Australian PBs, the power sharing was more profound and the deliberation deeper than typical. Not only did these PBs encompass the entirety of the government expenditure in this region, they also started with a pre-commitment to citizen influence on that budget [132]. Although the governing legislation of the City of Greater Geraldton did not allow delegation of budget setting, the elected Council committed to seriously consider all panel recommendations and, where they could not be implemented, publicly explain why and try to implement the spirit of the recommendations.

The deliberation was designed as intrinsic to the PBs and monitored throughout its execution. Again, these case studies present a prima facie valid intervention of partnership.

\subsection{Measurement Strategy}

To test the proposed intervention requires measurement of its deliberative democratic nature, as well as of any changes in participation and trust. As expected from a three-variable system - the trustor, the trustee, and the distinctive issue in the specific situation [133] —-the measurement of the attitude of trust is complex and nuanced. Numerous tools have been applied to this task, each with strengths and weaknesses [23,134]. The intervention in the case studies applied a mixed-methods approach, combining quantitative surveys with direct observation, document analysis, and qualitative interviews [135].

Semi-structured face-to-face interviews were held with 25 of the 63 panelists, five of the 15 elected Members of the Council, and 11 of the staff involved in the planning and execution of the mini-publics. These were conducted in a reflexive and receptive manner to acknowledge the interpretive nature of trust assessments [136-138], transcribed, and analyzed thematically [139] using NVivo 11. In line with our inductive/abductive approach, theming was conducted at a semantic level without explicit influence of pre-existing frames but with an awareness of possible researcher biases [139]. This commonly used thematic analytic method allowed for particular patterns or themes to emerge which are represented in our analysis through specific quotes presented verbatim. Using such word-for-word quotes gives authenticity and explanatory depth of the survey results. The interview material was supplemented by direct observation of participants and staff, daily deliberation debriefings, document analysis, and observation of the Greater Geraldton Council's budget meetings.

Quantitative surveys were administered to the wider community as well as the mini-public participants prior to the beginning of the intervention, at the midpoint of the sitting days, and at the end of the Panel deliberations. The trust surveys implemented were based on the General Social Survey (GSS) and other proxies for trust (such as confidence, honesty, loyalty, and fairness) used previously in analyzing PBs [140] and considered to be valid and accurate [141]. A positively phrased wording was applied to avoid associations with distrust [7]. The recommended long scale, seven-point Likert items 
(ranging from $1=$ strongly agree to $7=$ strongly disagree) were used [142] and produced high internal consistency, with the trust proxy questions from the GSS behaving in the same manner as the headline: "I believe that, overall, the City of Greater Geraldton is trustworthy" question. Since it is very difficult and highly contextual to link individual government functions to overall trust in government [18], we have focused on the headline metric for our analysis, as we feel it accurately tells the story. We also use an aggregative term ("City of Greater Geraldton") to measure the participants' overall assessment of the trustworthiness of the political actors associated with the local government.

Participation was measured using the Arnstein ladder scale which was deemed a particularly useful tool in this instance in spite of some valid criticisms that it oversimplifies complex governance and inappropriately uses norms in a quantitative scale [143-145]. Its use of norms was a benefit in this case because it allowed for measurement of subjective citizen values as well as empirical assessments, and pilot testing found it was easily understandable and educative for the average participants compared to more sophisticated tools. The scale did not presuppose a collaborative relationship and it also allowed comparison with previous studies [55]. Since a deliberative democracy intervention was also being tested, a number of indicators for representativeness, influence, and deliberativeness were measured [146]. Issues related to the representativeness of the sample demographics and attitudes were similarly assessed to ensure external validity with the wider population [147].

The following section describes the results from this mixed-methods case studies.

\section{Results}

Our results are focused on answering three questions to confirm the formulated hypothesis. First, "Did the intervention validly test as a deliberative democratic intervention with the attributes of a partnership relationship?" If this is the case, then: "Did the trust attitudes of the participants improve over the course of the intervention?" and finally: "Was there an association between the increase in public participation in government through the PBs and the improvements in the trust in government?" These issues are discussed in turn.

\subsection{Quality of the Interventions}

The representativeness criteria necessary for a deliberative democratic intervention were primarily achieved by creating a mini-public representation of Greater Geraldton using its demographic characteristics. This was relatively successful with respondents in both the community surveys and the Panels approximating the demographics of the region in terms of gender and geographical distribution, though with fewer youth than expected based on the Australian census data [132,148].

Demography is often a useful proxy for attitudes but to confirm the generalizability of the sample's results, a direct check on attitudinal representativeness was carried out by comparing the community and Panelist surveys. The Panels' attitudes toward participation in government mirrored those of the community (and were similar to overseas data) [55], with the exception of the members of the mini-publics rating the current relationship higher on the participatory ladder than the general community. This is likely because at the time of the survey they had already accepted their invitation to be part of a highly participatory intervention.

With regard to trust attitudes, since the data was ordinal with independent variables from independent groups and non-normally distributed, a non-parametric Mann-Whitney U-test was conducted for significance. For the Capital Works Panel, it indicated that trust in government by the mini-public (mean rank $=56.38, n=24$ ) was higher than those of the community (mean rank $=79.71, n=127), \mathrm{U}=1053, \mathrm{z}=-2.45$ (corrected for ties), $p=0.014$, two-tailed. This effect can be described as "small" ( $r=0.19)$ [149]. For the Operations Panel, trust in government by this mini-public (mean rank $=61.55, n=29$ ) was also higher than those of the community (mean rank $=82.37, n=127$ ), $\mathrm{U}=1350, \mathrm{z}=-2.302$ (corrected for ties), $p=0.021$, two-tailed. This effect can be described as "small" $(r=0.18)$. The respective points are illustrated in Figure 2. Note that due to the nature of the Likert scale used, higher ranks indicate less trust and the statistical relationship is negative (thus $\mathrm{z}$ has negative 
values). In summary, trust attitudes were well represented, but Panelists were slightly more trusting of government than the overall community.

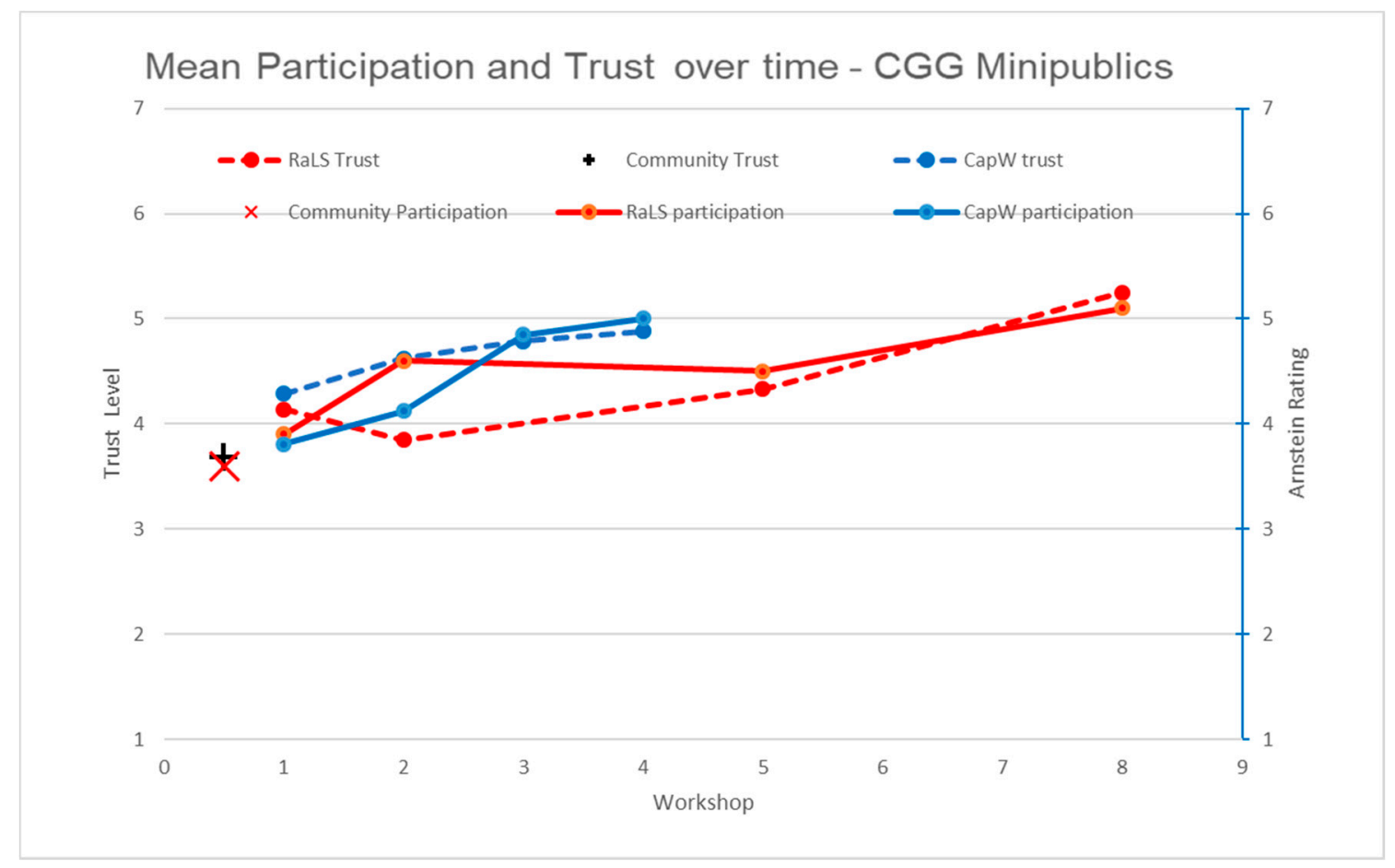

Figure 2. Trust and participation over the course of the City of Greater Geraldton (CGG) participatory budget mini-public.

Assessing the deliberativeness criteria of deliberative democracy revealed that most participants rated highly the quality of their deliberations including neutrality, access to information, ability to hear and be heard, and authenticity of outputs in daily surveys [108]. As is generally typical of PBs [124], the final deliberative democratic characteristic of the amount of influence was high. At the conclusion of both PB Panels, their recommendations were submitted to the elected Council of Greater Geraldton $[132,148]$. The recommendations were endorsed and formed the budget of the following year as well as the upcoming infrastructure program. Despite the contentious nature of the budgetary process in Geraldton prior to these interventions, there was no public or elected official dissention to these budgets [150].

Considering how highly the PBs scored on the representation, deliberation, and influence metrics, the cases studies clearly constituted a deliberative democratic intervention likely to shift the relationship between citizens and political actors to partnership and increase political trust. The quantitative and qualitative assessment of whether this did actually happen now follows.

\subsection{Quantitative Trust Results}

Figure 2 shows the mean trust and participation assessments of the Panelists over the two PBs. While the use of mean values to characterize ordinal data can be contested [151], the practice is common in the analysis of trust and this convention is followed here to enable comparisons. However, in our statistical analysis, non-parametric tests were applied to check internal validity. As it is a common practice to graphically represent increasing scale values as representing higher trust, we have inverted the mean trust data in Figure 2 to follow this convention.

Visually, the data indicates that political trust improved over the duration of both PBs. A participant self-assessment of whether trust had increased confirmed this with $78 \%$ of all Panelists believing their trust in the City of Greater Geraldton had increased over the PBs. A Friedman two-way ANOVA on 
the ordinal, non-normal survey data was applied to statistically verify this impression. For the Capital Works Panel, trust attitudes improved in a statistically significant manner from the first workshop participants attended, to the final workshop, $\chi_{\mathrm{F}}{ }^{2}=8.107$ (corrected for ties), $\mathrm{df}=3, n$-ties $=16, p=0.044$. Post-hoc analysis of pairwise comparison with Wilcoxon signed-rank tests was conducted with a Bonferroni correction applied, resulting in a significance level set at $p<0.0125$. There were statistically significant differences between the first and fourth workshop trust levels $(Z=-2.719, p=0.007)$ and almost between the second and fourth workshops $(Z=-2.324, p=0.020)$; however, not between the other trust pairs, that is between the first and second workshop $(Z=-1.493, p=0.135)$, the first and third workshop $(Z=-1.768, p=0.077)$, the second and third workshop $(Z=-0.277, p=0.782)$, and the third and fourth workshop $(Z=-0.847, p=0.397)$. Following Cohen's rough boundaries for labelling the significance of results to also reflect importance, the effects for these significant figures can be classified as large- or medium-sized [149].

For the Operations Panel, Workshop 1 was a non-mandatory introductory session and in statistical treatments Workshop 2 was considered to be more representative of the totality of attitudes. During this attendance period participant trust attitudes also improved in a statistically significant manner; $\chi_{\mathrm{F}}{ }^{2}=19.895$ (corrected for ties), $\mathrm{df}=2, n$-ties $=24, p=0.001$. Post-hoc analysis of pairwise comparison with Wilcoxon signed-rank tests was conducted with a Bonferroni correction applied, resulting in a significance level set at $p<0.017$. There were statistically significant differences between the fifth and eighth workshop trust levels $(Z=-3.206, p=0.001)$ and between the first and eighth workshops $(\mathrm{Z}=-3.797, p=0.001)$, but not between the first and fifth workshop trust levels $(\mathrm{Z}=-1.274, p=0.203)$. Following Cohen (2013), the effects for these comparisons were classified as large.

In short, while there were clearly statistically significant increases in trust over both PBs, the patterns of this shift were intriguing and require interpretation. Despite the Operations PB being double the duration of Capital Works PB to cover a more diverse range of budget activities, the improvements in trust and participation were equivalent. This is good evidence that as long as governance actions implement deliberative democratic principles that meet participation expectations, the virtuous trust dynamics are highly likely to function-regardless of duration and scale of complexity. As the first two workshops for both Panels did not result in statistically significant trust improvement, this could mean that individuals were still forming their trust opinions and hence they were in a state of attitudinal flux. Interviews with both participants and Greater Geraldton staff confirmed an initial phase of dislocation before partnerships manifested, particularly to gain competence in an unfamiliar area. As one Capital Works Panelist expressed: "We did have to get to know each other then get to know what we were doing. As the weeks went by, it got easier to fall into the groove and start doing what we needed to do." Another Operations Panelist summarized: "Some people got it straight away and some didn't ... I personally found the majority of people found 'it' around week four." The lack of statistically significant change between the third and fourth workshops in the Capital Works Panel was also interesting. It could reflect a stabilization of attitudes toward the end of that PB (where there were four measurements over four workshops) compared with the Operations Panel (where there was a larger spread between measurements, i.e., three over eight workshops).

For the Panelists, Figure 2 clearly shows trust ratings increased as the assessment of the participation level rose toward partnership (Level 6) over the course of the PBs. The broader association between participation and trust in a population can be best established in the community survey and was statistically confirmed for these two independent, ordinal variables using Kendall's Tau-B test. It indicated a strong and significant association between participation and trust in government (Tau $=-0.296, p<0.001, n=127$ ) as well as with all other trust proxy questions used.

The danger of a demand effect or Hawthorn effect confounding these results is possible because of the methods used. This effect concerns experimental subjects changing their behavior because of their mindfulness of being observed [152] but we believe it is small for the following reasons:

- As we shall see in Section 5.2, the Greater Geraldton case studies produced large magnitude effects compared to previous studies also with deliberative interventions implying such effects are 
not dominant. In addition, other studies have used different types of participation interventions and produced different magnitudes of changes in trust also implying these effects are not significant [128].

- The important results above concern longitudinal changes in trust and participation. Over multiple retesting any powerful novelty or demand effects would be expected to lessen and cause any trends to regress compared to initial measurements-neither of which occurred.

- These effects are often exacerbated when the results of measurements are fed back to participants or researchers react to results, neither of which occurred during the PBs.

- There was no indication in the qualitative interviews that the participants were subject to any experimental demand effects. Observations by the authors also detected no evidence of these effects and no motivation to 'please' the researchers (particularly when completing surveys after the cognitive weariness that comes from hours of deliberation).

Hence, any mechanism that relies on the explanation that the respondents were able to discern the intentions and biases of the researchers for no obvious gain, starts to strain credulity. Parsimony would then dictate we conclude such effects were negligible.

\subsection{Qualitative Trust Results}

The qualitative analysis helps give weight and depth to the above statistical findings regarding the deliberative democratic process, the nature of partnership but also to confirm our understanding of trust as a combination of competence and benevolence. Interview analysis of both participants and staff reinforced the idea that improvements in trust were linked to a need for partnership [55] and this was seen as superior to the existing regime with its sporadic voting and barriers to participation for non-expert citizens. Most succinctly this was expressed by a citizen as: "I think they are doing a good job but they can only do that if we all help out."

The interviews with Panelists revealed this sentiment had its root in aspects of the design and process that encouraged them to act benevolently and produce competent, deliberative outputs (see Table 1). The process also created conditions where citizens and political actors could observe and assess the competence and benevolence of the other party (see Table 2).

Table 1. Examples of citizen perceptions of the importance of competence and benevolence.

\begin{tabular}{|c|c|}
\hline Assessments of Competence & Assessments of Benevolence \\
\hline $\begin{array}{l}\text { "It's like running a small country, isn't it? I never thought } \\
\text { there was so many departments-I never gave it a } \\
\text { thought."-Panel Member }\end{array}$ & $\begin{array}{l}\text { "With this process, at least you are getting a random selection } \\
\text { of people that are getting a say. And they are real people. } \\
\text { They are not undercover, guerrilla politicians just trying to } \\
\text { change things. It's how it should be."-Panel Member } \\
\text { "It's a good way to have a say in what's going on as long as } \\
\text { that's always tempered by -you are here as a representative. }\end{array}$ \\
\hline $\begin{array}{l}\text { "It didn't matter if we had difference of opinion, we listened } \\
\text { well to each other, we explained well and then we reached } \\
\text { an understanding and agreement and then moved onto the } \\
\text { next thing."-Panel Member }\end{array}$ & $\begin{array}{l}\text { At those meetings I brought up things that I personally don't } \\
\text { agree with. But that being said, I know that a lot of my friends } \\
\text { and people at work do. So, I still have my view, but I go: } \\
\text { 'These people do have some good points, maybe I will include } \\
\text { them in what I am doing'. It's about getting the best outcome } \\
\text { for everybody." - Panel Member }\end{array}$ \\
\hline $\begin{array}{l}\text { "But I was also being informed as to the whole process-it } \\
\text { gave us the information, set us up in a process that allowed } \\
\text { us to make decisions based on that."-Panel Member }\end{array}$ & \\
\hline
\end{tabular}


Table 2. Examples of government and citizen perceptions of mutual competence and benevolence.

\begin{tabular}{|c|c|}
\hline Assessments of Competence & Assessments of Benevolence \\
\hline $\begin{array}{l}\text { "... you use processes to get the best out of the community ... they } \\
\text { aren't stupid_common sense prevails ... there hasn't been a single } \\
\text { result that we have said:'Where on earth did that come } \\
\text { from?'"-Staff Member } \\
\text { "The mind boggling the amount of money they have to juggle around } \\
\text { and the amount of projects they have to deal with ... . Over the } \\
\text { course of the eight weeks my mindset changed from one of } \\
\text { questioning:'What the Council was doing?' to 'They're doing a } \\
\text { pretty good job under the circumstances.'"-Panel Member } \\
\text { "... we all know that if you send money one way then it doesn't go } \\
\text { another. It was really hard to come to fair budget ... and of course } \\
\text { when you are handling other people's money you need to be more } \\
\text { accountable."-Panel Member }\end{array}$ & $\begin{array}{l}\text { "They owned those values ... when that clicked into } \\
\text { place - how important it was for them to come up with } \\
\text { their own values ... because there was so much passion in } \\
\text { the room."-Staff Member } \\
\text { "The process itself was fantastic. The people at the } \\
\text { Council-the Directors—their passion, their interest and } \\
\text { their willingness to give it a go sort of makes you feel you } \\
\text { are in fairly good hands considering the reputation they } \\
\text { have had."-Panel Member }\end{array}$ \\
\hline
\end{tabular}

Conditions of anxiety and competitiveness have been known to spur shallow thinking that is associated with negative trust $[76,153]$, however, the Panelists discussed feeling safe expressing and hearing opinions that dissented from their own (see Table 3). This is an important part of the equality of political speech in deliberation and the participants described deliberative shifts in their-and other people's-opinions.

Table 3. Examples of Panelist perceptions of the value of deliberative process and environments.

\footnotetext{
"But this is just the reality of living in society and if you get a cross-section of people. I found the small groups really good."

"My mind was definitely opened with people's opinions and I definitely think hearing different stories and from people who are passionate about things makes you go-'Oh that's interesting, I didn't think about that.' So, you become more openminded."

"There was a few times there where they said 'Oh I didn't think about that.' That makes me happy—at least they were listening. They may not change but at least they have heard the argument for the other side."

"... I said-'hang on a minute here-we are supposed to be making decisions for people out there in the community not just because it is something that we disagree with and we don't like."'

"I think it was brilliant the way they did it ... . I really like the idea of going around to each of the tables and making a decision on each of those. Rather than making a decision on one thing you see the whole thing - which was really good."
}

Lastly, from a practical process point of view, the Panelists noted the importance of being officially welcomed and greeted effusively at every meeting, having uncomfortable chairs replaced, and being provided with quality refreshments during the workshops. Relatively unimportant operational specifics of the deliberations, "greeting, seating, and eating," apparently concretely and immediately signaled components of cognitive as well as affective (emotion-based) trust.

\section{Discussion}

In this discussion we start by commenting on the applicability of the analysis beyond the two Greater Geraldton case studies. Following this, we outline the implications of this data for showing how governments can increase trust in transitioning to sustainability and the importance of trust in government for the implementation of sustainability-based initiatives.

\subsection{Generalizable Nature of the Case Studies}

These case studies clearly support the hypothesis that a partnership relationship underlies significant trust improvements, a result made more useful by comparison with data from other contexts. The baseline Greater Geraldton trust levels at least seem to be comparable with background trust levels in other western nations. For example, a 2001 Norwegian survey showed a similar mean of local government trust-3.86 (when converted to our seven-point scale) [20]. This is congruent with other research [23], and particularly a question from a survey by the International Social Survey Program 
(ISSP) across 33 countries which asked about trust in public servants [26]. Hence, this gives confidence the results from the Greater Geraldton case studies would be applicable outside their context.

\subsection{An Analytical Tool for Designing and Explaining the Effect of Participation on Political Trust}

The analysis above allows two robust conclusions. First, it overwhelmingly supports our hypothesis that political trust is powerfully influenced by the type and style of participation and changing creates significant improvement. Secondly, it confirms that the framework of understanding trust and participation we laid out at the beginning of this article is useful as a tool for designing interventions to improve trust. The conceptual breakdown of trust into benevolence and competence components in combination with awareness of the citizens' preference for partnership allows us to explain why some types of public participation are more (or less) effective in increasing trust. An example is the improvement in trust seen in the participants over the course of the PBs which represents the effect of moving from informing/consulting to partnership participation. However, the framework we have outlined can also be used to compare and explain differences on a finer scale. The most directly comparable intervention to our case studies is a deliberative PB in Lincoln, Nebraska. Just like in Greater Geraldton, the participants in Lincoln showed statistically significant increases in confidence, trustworthiness and belief in the benevolence and competence of the local government [140]. However, compared with the Lincoln case study, the Geraldton participants experienced a 3-4 times greater increase in trust (after converting different survey scales). On the face of it this result is problematic-how could two apparently similar interventions produce such a varying strength of effect?

There are two likely possibilities, both of which concern the design and implementation of the PBs. The first is that pre-deliberation trust levels of the Lincoln PB participants were already high-1.69 (Lincoln scale adjusted) compared to 3.15 (Operations PB), and 2.71 (Capital Works PB), and very high compared to the Greater Geraldton community (3.76). Given that general political trust in the US is at least as low as in Australia, this high initial level was likely due to a selection bias in the participants of the Lincoln PB. While this bias was a factor in obtaining attitudinal representation in Geraldton [55], it was accentuated in Lincoln, Nebraska, where the online recruitment methods used produced a sample which is more male, white, educated, and liberal than the broader population $[140,154,155]$. Increasing political trust in a group already certain of the trustworthiness of government would be difficult [156], and hence the possible increase in a more representative group of Nebraskans could actually be greater than that documented and the strength of the effect of partnership can be mismeasured.

However, we believe it is unlikely that this would explain the differences in their entirety. Our dominant explanation for the larger trust gains in Australia is the greater realization of the partnership ideal of participation. We have already highlighted previously that there are degrees of deliberativeness in PBs and modelling has shown that increased opportunities to deliberate with dissent in a fine-grained manner produce an epistemically stronger and more authentic common will [157]. Public engagement case studies have also found a strong relationship between higher levels of design and process management and improvements in government/Panelist outcomes and satisfaction [158]. Bearing this in mind, although there were elements of similarity in the PBs in both countries, there was significantly more deliberation of higher quality in the Greater Geraldton PBs. The Nebraskan Panel sat for a single day and made recommendations based on two rounds of presentations, facilitated small group discussions, and questions and answers plenaries. The Capital Works Panel met for four and a half days and created a multicriteria analysis rating system based on deliberated values with multiple rounds of presentations and interrogation of 130 proposed infrastructure projects. Similarly, the Operational Panel met for eight days, again determining criteria/values to assess service levels for 30 operational areas as well as specific service level suggestions. As more descriptively accurate representative mini-publics compared to Nebraska, the legitimacy of their common will formation was higher. Taken together, this allowed Panelists and government to display greater competence and benevolence in a more equal power-sharing arrangement, than in Lincoln. Overall, we believe 
the Greater Geraldton trust results are probably more generalizable to typical populations and the realization of partnership was fuller, as implied by our framework.

\subsection{Implications for Sustainability}

There is very limited information on whether citizens trust government to specifically be able to address sustainability transition-either as a standalone issue or as a wicked problem [34-36]. The discussion below offers some insights on this topic and elaborates on ways to build trust in government.

\subsubsection{The Role of Political Trust for Governments Implementing Sustainability}

The results from the Greater Geraldton case studies and understanding of political trust could be useful in the implementation of sustainability. The core of the importance of trust to sustainability lies in the wicked nature of sustainability problems. Governments face a proliferation of such wicked problems [159] with sustainability having all the hallmarks of wickedness [160], such as:

- High consequences of inaction or failure to address the problem;

- No definitive statement of the problem with its parameters defined differently depending on the perspective and continuously revealed, unexpected dimensions of the problem in response to attempted solutions; furthermore, settling on an acceptable statement (and solution) requires value judgements;

- No end-point defined, and even its existence is uncertain; often only improvement or degradation in the status can be determined;

- $\quad$ Limited ability to generalize from other solutions to the existing problem.

These wickedness properties are clearly demonstrated during attempts to implement the common framework of the United Nations Sustainable Development Goals [150,161].

Uncertainty is the defining characteristic of wicked vs. tame problems-not just the limited, controlled uncertainty of tame problems that governments are accustomed to managing, but the nonlinear and epistemic uncertainty. This involves uncertainty in the very definition of the problem, uncertainty of an end-point, and uncertainty in the effect of solutions. In the case of sustainability, this uncertainty is further magnified when the issues entrain entities from across state and organizational borders with their own histories, perspectives, and agendas [162]. Perversely, the only certainties are that mistakes will be made, solutions will be incomplete, disagreements will arise, and learnings will be contingent and narrow. This is the critical role that trust can play and the role it has traditionally played in human relationships, markets, and governance-as a tool for managing uncertainty. Networks with low trust between parties would become paralyzed or act counterproductively when facing the uncertainty of wicked problems $[163,164]$. With sustainability, this is particularly true, since a collaborative approach is universally recommended $[165,166]$. When faced with failed solutions, shifting parameters, and value-based conflict over the nature of the problem and possible solutions, trust is required to keep governments and citizens reengaging with the solutions, redefining the problem, committing resources, and contesting these decisions in a constructive manner.

We have previously proposed [150] that deliberative democracy is useful to sustainability practitioners, because it creates governance conditions that are suitable for implementing a sustainability agenda due to its wicked nature. In this article we have shown that deliberative democracy is useful beyond being an effective governance mode as it also produces increases in trust that are necessary for the partnership between citizens and governments required to address sustainability well. This would embody the partnerships for sustainability called for by the UN as one of the Sustainable Development Goals (SDG17) [167], but instead of a global focus they would apply between governments and citizens at national, state, and local levels. 


\subsubsection{Ways of Building Trust in Government for Implementing Sustainability}

Since trust is made up of two components-competence and benevolence, we can now be even more specific regarding what competence and benevolence governments will need to demonstrate to generate the political trust required for implementing and mainstreaming sustainability. The competencies that need to be demonstrated when facing wicked problems, particularly sustainability, have been outlined in our previous work [150] and include the following:

- The recognition of the epistemic challenge of the wicked problem: Identification of the fundamental nature of the problem provides a starting point for the following competencies;

- The ability to make collective value judgements: Since there is divergence on the very nature of the problem and possible solution then a series of value judgements-not just of individuals, but also public ones-must be made collectively [168];

- The ability to use and integrate diverse inputs: An approach consisting only of experts and technocrats will be inadequate to deal with the uncertainty around the diagnosis and resolution of wicked problems as they emerge and evolve $[160,169]$. A scientific, evidenced-based perspective can lay out a partial "map" of the problem/solution space $[170,171]$ but the value judgements of politics [172] and diverse knowledge domains [173] are best to navigate it, particularly the associated risks, costs, and benefits;

- The use of deliberative communication modes: Deliberative communication involves the public exchange of reasons between persons representing different perspectives on a problem, rational reflection, and justification of possible solutions. Deliberative discussion has greater epistemic strength than alternatives [83] and represents opportunities for either opinion change or at least clarification of areas of agreement/disagreement. This is well-suited to the wicked problem issues of determining stopping points and what constitutes a better or worse solution [172,174,175];

- The distribution of power combined with collaborative action: The shift in nature of wicked problems and its interpretation in different contexts mean that centralized and unshared power is usually too slow or too unnuanced to effectively address sustainability. Opportunities for collaboration around action, learnings, and resources should also be taken advantage of at the discretion of the actors which has led to the UN recommending models of distributed and collaborative power for the SDG [176-178].

Beyond these competencies, demonstrations of benevolence will also need to be developed for maximum trust. Benevolence is often signaled through process design-that this, how the above competencies are conceived, planned, and implemented. Examples of how the orientation toward the good of the whole can be demonstrated in each of the above competencies might be:

- Recognition of the difficulty and nature as the first step can be seen as a sign of honesty and orientation toward addressing a systematic threat to the common good-as opposed to ignoring it or trying to downplay the role of government or its significance;

- The making of collective value judgements in a way that can be seen to legitimately represent some version of the common good maxim, rather than privileging narrow interests, political ideology, or the powerful;

- The inviting and eliciting of diverse inputs for any value judgement in a manner that can be justified as being from a wide-enough group of sources to constitute a collective decision. The process for achieving this should actively value each input to the collective synthesis and transparently represent the contribution of each part of the whole solution;

- The deliberative communication is conducted with equality of speech between participants and based on information and data agreed to be neutral or at least representative of multiple perspectives $[88,105]$. Although it is impossible to claim that the use of any data is value-neutral, deliberative democratic processes have been successful in creating bodies of agreed information and data sources with high legitimacy. Examples include: the use of interest/advocacy groups 
to produce common statements of agreed facts or at least clear statements of their perspectives for consideration (cf. Danish Consensus Conferences [179,180]); allowing mini-publics to call witnesses to present perspectives and discourses (cf. Eastern Australian Citizens' Juries [102]); and creating a mini-public dedicated to producing a consensual statement of facts (cf. Oregon Citizens' Initiative Review [181]). The legitimacy such processes confer on the deliberative discussion provides assurance to partners that the inevitable mistakes and unintended consequences of wicked problems are not intentional or manipulated by any party in this contested space;

- The collaborative sharing of the concentrated power of government can provide the most important signal of the intent to work toward a common good, especially in light of the high stakes implicit in the wicked problem.

\subsubsection{Possibilities and Limitations of Trust Building}

A government wishing to build trust by following the above recommendations now has a framework and a validated tool-deliberative democratic mini-publics-that together form an effective way to establish political trust with citizens who are involved in their governance. These mini-publics can also be used as trusted proxies for the wider populace that may not be directly involved as well. Research has shown that voters assess them as competent, benevolent, and more trustworthy than state legislatures $[17,182,183]$. We concur with trust scholars that it is unlikely that a mini-public-based dynamic will entirely close or resolve political trust issues in the current system [17] and that sometimes governments cannot and should not be trusted [184]. In spite of these caveats, mini-publics have proven themselves valuable to building sustainability-supporting trust, and should be combined with other ways to signal benevolence and demonstrate competence, such as control of donations, changes to parliamentary entitlements, independent corruption watchdogs, and media regulation [35].

There are many areas we have left unexplored and can be subjects for future research. For example, one of them is how a trust framework could be created between policy actors who support and who do not support a sustainability agenda. Beyond this, the paradigm-shifting possibility for harnessing the repetitive aspect of the wicked nature of sustainability looms large. The need to revisit sustainability issues as the problem morphs and values are renegotiated, is usually negatively framed as a challenge. However, this may only be true in the current governance systems which approach wicked problems in such a way that constantly degrades trust because of the relationship between government and citizens. If governments' and citizens' assessment of the competency and benevolence of each other improved and was built up each time a wicked problem was iterated (i.e., trust increased), then the repetitive nature of sustainability implementation would be reimagined as a strength. Now each time a problem was deliberated upon, relationships would improve, collective epistemic value would grow, and trust would build. This would constitute a cycle that had changed from vicious to virtuous.

\section{Conclusions}

While obviously more case studies and further research are needed to corroborate these findings, based on the two Greater Geraldton participatory budgeting interventions we feel confident in asserting the following statements. Political trust is very important for governments trying to successfully implement a sustainability agenda. Changing governments' relationship with their citizens through public participation is an accessible and effective way to increase political trust. The term "public participation" is often used as a catch-all to describe a range of interactions between government and citizens but it is clear this phrase obscures more than it reveals. Creating partnership is critical to achieving the relationship citizens desire and boosting trust. The established theory of deliberative democracy supports a partnership relationship by emphasizing competence and benevolence of the government and the governed. The Greater Geraldton PBs affirm that the actualization of the theory through mini-publics produced such partnerships and generated increases in political trust. This can provide the bond of trust that on the shifting, uncertain, and wicked seas 
of sustainability both sides need to be assured of the competency and intentions of the other when navigating these waters.

Author Contributions: All authors conceptualised this study; R.W. collected and analysed the empirical data and drafted the article; all authors made contributions throughout all sections. All authors have read and agreed to the published version of the manuscript.

Funding: This research received financial support provided by the Australian Research Council Linkage grant (No. LP100200803).

Acknowledgments: The authors would like to acknowledge the contribution of an Australian Government Research Training Program Scholarship in supporting this research. They are also thankful to the three anonymous referees whose comments helped improve the quality of the manuscript.

Conflicts of Interest: The authors declare no conflict of interest.

\section{References}

1. Saunders, M.; Lewis, P.; Thornhill, A.; Bristow, A. Understanding research philosophy and approaches to theory development. In Research Methods for Business Students; Saunders, M., Lewis, P., Thornhill, A., Eds.; Prentice Hall: London, UK, 2009; pp. 122-161.

2. Yanow, D.; Schwartz-Shea, P. Interpretive Approaches to Research Design: Concepts and Processes; Routledge: New York, NY, USA, 2011.

3. Rousseau, D.M.; Sitkin, S.B.; Burt, R.S.; Camerer, C. Not so different after all: A cross-discipline view of trust. Acad. Manag. Rev. 1998, 23, 393-404. [CrossRef]

4. Simpson, J. Psychological foundations of trust. Curr. Dir. Psychol. Sci. 2007, 16, 264-268. [CrossRef]

5. Mayer, R.C.; Davis, J.H.; Schoorman, F.D. An integrative model of organizational trust. Acad. Manag. Rev. 1995, 20, 709-734. [CrossRef]

6. Albrecht, S.L. Perceptions of integrity, competence and trust in senior management as determinants of cynicism toward change. Public Adm. Manag. Interact. J. 2002, 7, 320-343.

7. McKnight, D.H.; Choudhury, V.; Kacmar, C. Developing and validating trust measures for e-commerce: An integrative typology. Inf. Syst. Res. 2002, 13, 334-359. [CrossRef]

8. Hoy, W.K.; Tschannen-Moran, M. The conceptualization and measurement of faculty trust in schools. In Essential Ideas for the Reform of American Schools; Hoy, W.K., DiPaola, M., Eds.; Information Age: Greenwich, CT, USA, 2007; pp. 87-114.

9. Simpson, J. Foundations of interpersonal trust. In Social Psychology: Handbook of Basic Principles, 2nd ed.; The Guilford Press: New York, NY, USA, 2007; pp. 587-607.

10. Drake, J.; Mehta, N. Benevolent Competence and Integrity-Based Trust in Knowledge Transfer: A Look at Software Reuse. In Proceedings of the Americas Conference on Information Systems (AMCIS) 2006, Acapulco, Mexico, 4-6 August 2006; Available online: https://aisel.aisnet.org/amcis2006/214 (accessed on 28 August 2020).

11. Keele, L. Social capital and the dynamics of trust in government. Am. J. Political Sci. 2007, 51, 241-254. [CrossRef]

12. Newton, K.; Zmerli, S. Three forms of trust and their association. Eur. Political Sci. Rev. 2011, 3, 169-200. [CrossRef]

13. Hetherington, M.; Rudolph, T. Why Washington Won't Work: Polarization, Political Trust, and the Governing Crisis; University of Chicago Press: London, UK, 2015.

14. Bannister, F.; Connolly, R. Trust and transformational government: A proposed framework for research. Gov. Inf. Q. 2011, 28, 137-147. [CrossRef]

15. Wang, X.; Wan Wart, M. When public participation in administration leads to trust: An empirical assessment of managers' perceptions. Public Adm. Rev. 2007, 67, 265-278. [CrossRef]

16. Easton, D. A Systems Analysis of Political Life; John Wiley: New York, NY, USA, 1965.

17. Warren, M.E.; Gastil, J. Can deliberative minipublics address the cognitive challenges of democratic citizenship? J. Politics 2015, 77, 562-574. [CrossRef]

18. Van de Walle, S.; Bouckaert, G. Public service performance and trust in government: The problem of causality. Int. J. Public Adm. 2003, 26, 891-913. [CrossRef] 
19. Hooghe, M.; Marien, S. A comparative analysis of the relation between political trust and forms of political participation in Europe. Eur. Soc. 2013, 15, 131-152. [CrossRef]

20. Christensen, T.; Lægreid, P. Trust in government: The relative importance of service satisfaction, political factors, and demography. Public Perform. Manag. Rev. 2005, 28, 487-511.

21. Gustavsen, A.; Pierre, J.; Røiseland, A. Participation or satisfaction? Examining determinants of trust in local government. Scand. J. Public Adm. 2017, 21, 3-16.

22. Kuklinski, J.H.; Quirk, P.J.; Jerit, J.; Schwieder, D.; Rich, R.F. Misinformation and the currency of democratic citizenship. J. Politics 2000, 62, 790-816. [CrossRef]

23. Marien, S. Measuring political trust across time and space. In Political Trust: Why Context Matters; Zmerli, S., Hooghe, M., Eds.; ECPR Press: Colchester, UK, 2011; pp. 13-46.

24. Van de Walle, S.; Van Roosbroek, S.; Bouckaert, G. Trust in the public sector: Is there any evidence for a long-term decline? Int. Rev. Adm. Sci. 2008, 74, 47-64. [CrossRef]

25. Dalton, R.J. The social transformation of trust in government. Int. Rev. Sociol. 2005, 15, 133-154. [CrossRef]

26. Van Ryzin, G.G. Outcomes, process, and trust of civil servants. J. Public Adm. Res. Theory 2011, 21, 745-760. [CrossRef]

27. Levi, M.; Stoker, L. Political trust and trustworthiness. Annu. Rev. Political Sci. 2000, 3, 475-507. [CrossRef]

28. Rudolph, T.J. Political trust, ideology, and public support for tax cuts. Public Opin. Q. 2009, 73, 144-158. [CrossRef]

29. Hetherington, M. Why Trust Matters: Declining Political Trust and the Demise of American Liberalism; Princeton University Press: Princeton, NJ, USA, 2005.

30. Kollmann, A.; Reichl, J. How trust in governments influences the acceptance of environmental taxes. In Political Economy and Instruments of Environmental Politics; Schneider, F., Kollmann, A., Reichl, J., Eds.; MIT Press: Cambridge, MA, USA, 2015; pp. 53-70.

31. Hetherington, M.; Husser, J. How Trust Matters: The Changing Political Relevance of Political Trust. Am. J. Political Sci. 2012, 56, 312-325. [CrossRef]

32. Evans, M.; Halupka, M.; Stoker, G. How Do Australians Imagine Their Democracy: The 'Power of Us'; University of Canberra, Institute for Governance and Policy Analysis, Museum of Australian Democracy, 2018. Available online: https://www.governanceinstitute.edu.au/magma/media/upload/publication/408_Democracy100report-IGPA.pdf (accessed on 28 August 2020).

33. Herian, M. Trust in government and support for municipal services. State Local Gov. Rev. 2014, 46, 82-90. [CrossRef]

34. Stoker, G.; Evans, M.; Li, J.; Halupka, M. Judging Democratic Politics in Australia: Exploring Citizens' Folk Theories. In Proceedings of the ECPR General Conference 2014-Do Democratic Innovations Matter for Citizens, Glasgow, UK, 4-6 September 2014; pp. 4-6.

35. Warren, M.E. What kinds of trust does a democracy need? Trust from the perspective of democratic theory. In Handbook on Political Trust; Zmerli, S., Meer, T.V.D., Eds.; Edward Elgar Publishing: Cheltenham, UK, 2017; pp. 33-52.

36. Thomas, J.C. Citizen, customer, partner: Rethinking the place of the public in public management. Public Adm. Rev. 2013, 73, 786-796. [CrossRef]

37. Tyler, T.R. Why People Obey the Law; Princeton University Press: Princeton, NJ, USA, 2006.

38. Shipley, R.; Utz, S. Making it count: A review of the value and techniques for public consultation. J. Plan. Lit. 2012, 27, 22-42. [CrossRef]

39. Lauber, T.B. Measuring fairness in citizen participation: A case study of moose management. Soc. Nat. Resour. 1999, 12, 19-37. [CrossRef]

40. Hibbing, J.R.; Theiss-Morse, E. Stealth Democracy: Americans' Beliefs about How Government Should Work; Cambridge University Press: Cambridge, UK, 2002.

41. Edelmen. 2015 Edelmen Trust Barometer; Edelmen: Chicago, IL, USA, 2015.

42. OECD. Risks That Matter: Main Findings from the 2018 OECD Risks That Matter Survey; OECD: Paris, France, 2019.

43. Van Lange, P.A. Generalized trust: Four lessons from genetics and culture. Curr. Dir. Psychol. Sci. 2015, 24,71-76. [CrossRef]

44. Quick, K.; Bryson, J. Public participation. In Handbook on Theories of Governance; Edward Elgar Publishing: Cheltenham, UK, 2016. 
45. Lamprianou, I. Contemporary political participation research: A critical assessment. In Democracy in Transition: Political Participation in the European Union; Demetriou, K.N., Ed.; Springer: Berlin/Heidelberg, Germany, 2013; pp. 21-42. [CrossRef]

46. Lamprianou, I. Introduction. In Democracy in Transition: Political Participation in the European Union; Demetriou, K.N., Ed.; Springer: Berlin/Heidelberg, Germany, 2013; pp. 1-17.

47. Jacobs, L.R.; Cook, F.L.; Carpini, M.X.D. Talking Together: Public Deliberation and Political Participation in America; University of Chicago Press: Chicago, IL, USA, 2009.

48. Gabriel, O. Participation and political trust. In Handbook on Political Trust; Zmerli, S., Van der Meer, T.W., Eds.; Edward Elgar Publishing: Cheltenham, UK, 2017.

49. Thompson, D. Deliberative democratic theory and empirical political science. Annu. Rev. Political Sci. 2008, 11, 497-520. [CrossRef]

50. VanderMolen, K. Stealth Democracy revisited: Reconsidering preferences for less visible government. Political Res. Q. 2017, 70, 687-698. [CrossRef]

51. Neblo, M.A.; Esterling, K.M.; Kennedy, R.P.; Lazer, D.M.; Sokhey, A.E. Who wants to deliberate-And why? Am. Political Sci. Rev. 2010, 104, 566-583. [CrossRef]

52. Dryzek, J. Handle with care: The deadly hermeneutics of deliberative instrumentation. Acta Politica 2005, 40, 197-211. [CrossRef]

53. Marien, S.; Christensen, H.S. Trust and openness: Prerequisites for democratic engagement? In Democracy in Transition: Political Participation in the European Union; Demetriou, K.N., Ed.; Springer: Berlin/Heidelberg, Germany, 2013; pp. 109-134.

54. Michels, A. Innovations in democratic governance: How does citizen participation contribute to a better democracy? Int. Rev. Adm. Sci. 2011, 77, 275-293. [CrossRef]

55. Weymouth, R.; Hartz-Karp, J. Participation in planning and governance: Closing the gap between satisfaction and expectation. Sustain. Earth 2019, 2, 5. [CrossRef]

56. Bailey, K.; Grossardt, T. Toward structured public involvement: Justice, geography and collaborative geospatial/geovisual decision support systems. Ann. Assoc. Am. Geogr. 2009, 100, 57-86. [CrossRef]

57. Arnstein, S.R. A ladder of citizen participation. J. Am. Inst. Plan. 1969, 35, 216-224. [CrossRef]

58. Arnstein, S. Eight rungs on the ladder of participation. In Citizen Participation: Effecting Community Change; Cahn, E., Passett, B., Eds.; Praeger: London, UK, 1971; pp. 69-91.

59. Bailey, K.; Blandford, B.; Grossardt, T.; Ripy, J. Planning, technology, and legitimacy: Structured public involvement in integrated transportation and land-use planning in the United States. Environ. Plan. Part B 2011, 38, 447. [CrossRef]

60. Bowler, S.; Donovan, T.; Karp, J.A. Enraged or engaged? Preferences for direct citizen participation in affluent democracies. Political Res. Q. 2007, 60, 351-362. [CrossRef]

61. Font, J.; Wojcieszak, M.; Navarro, C.J. Participation, representation and expertise: Citizen preferences for political decision-making processes. Political Stud. 2015, 63, 153-172. [CrossRef]

62. Coffé, H.; Michels, A. Education and support for representative, direct and stealth democracy. Elect. Stud. 2014, 35, 1-11. [CrossRef]

63. King, C.S.; Feltey, K.M.; O'Neil Susel, B. The question of participation: Toward authentic public participation in public administration. Public Adm. Rev. 1998, 4, 317-326. [CrossRef]

64. Innes, J.E.; Booher, D.E. Reframing public participation: Strategies for the 21st century. Plan. Theory Pract. 2004, 5, 419-436. [CrossRef]

65. Fishkin, J. Strategies of public consultation. Integr. Assess. 2006, 6, 57-72.

66. Gaynor, A.; Newman, P.; Jennings, P. Never Again: Reflections on Environmental Responsibility after Roe 8; UWA Publishing: Perth, Australia, 2018.

67. Laurian, L.; Shaw, M.M. Evaluation of public participation: The practices of certified planners. J. Plan. Educ. Res. 2009, 28, 293-309. [CrossRef]

68. Grönlund, K.; Setälä, M. Political trust, satisfaction and voter turnout. Comp. Eur. Politics 2007, 5, 400-422. [CrossRef]

69. Pew Research Center. The Public, the Political System and American Democracy; Pew Research Centre: Washington, DC, USA, 26 April 2018.

70. Hendriks, C. The ambiguous role of civil society in deliberative democracy. In Proceedings of the Australian Political Studies Association Meeting, Canberra, Australia, 2-4 October 2002. 
71. Briggs, L. Tackling Wicked Problems: A Public Policy Perspective; Australian Public Service Commission: Canberra, Australia, 2007.

72. Rosell, S.; Gantwerk, H. Moving beyond polls and focus groups. In Toward Wiser Public Judgment; Yankelovich, D., Friedman, W., Eds.; Vanderbilt University Press: Nashville, TN, USA, 2011; pp. 110-130.

73. McFall, L. Integrity. Ethics 1987, 98, 5-20. [CrossRef]

74. Dowell, D.; Morrison, M.; Heffernan, T. The changing importance of affective trust and cognitive trust across the relationship lifecycle: A study of business-to-business relationships. Ind. Mark. Manag. 2015, 44, 119-130. [CrossRef]

75. Holmberg, S.; Rothstein, B. Trusting other people. J. Public Aff. 2017, 17, e1645. [CrossRef]

76. Rempel, J.K.; Holmes, J.G.; Zanna, M.P. Trust in close relationships. J. Personal. Soc. Psychol. 1985, 49, 95. [CrossRef]

77. Baumeister, R.F.; Bratslavsky, E.; Finkenauer, C.; Vohs, K.D. Bad is stronger than good. Rev. Gen. Psychol. 2001, 5, 323-370. [CrossRef]

78. Kampen, J.K.; De Walle, S.V.; Bouckaert, G. Assessing the relation between satisfaction with public service delivery and trust in Government. The impact of the predisposition of citizens toward Government on evalutations of its performance. Public Perform. Manag. Rev. 2006, 29, 387-404.

79. Kuyper, J.W. The instrumental value of deliberative democracy-Or, do we have good reasons to be deliberative democrats? J. Public Delib. 2018, 14, 1. [CrossRef]

80. Mollering, G. Trust: Reason, Routine, Reflexivity; Elsevier: Amsterdam, The Netherlands, 2006.

81. Herian, M.; Hamm, J.; Tomkins, A.; PytlikZillig, L. Public participation, procedural fairness, and evaluations of local governance: The moderating role of uncertainty. J. Public Adm. Res. Theory 2012, 22, 815-840. [CrossRef]

82. Tomkins, A.; PytlikZilllig, L.M.; Herian, M.N.; Abdel-Monem, T.; Hamm, J.A. Public input for municipal policymaking: Engagement methods and their impact on trust and confidence. In Proceedings of the 11th Annual International Digital Government Research Conference on Public Administration Online: Challenges and Opportunities, Puebla, Mexico, 17-20 May 2010; pp. 41-50.

83. Landemore, H. Democratic Reason: Politics, Collective Intelligence, and the Rule of the Many; Princeton University Press: Princeton, NJ, USA, 2013.

84. Fishkin, J. When the People Speak: Deliberative Democracy and Public Consultation; Oxford University Press: Oxford, UK, 2009.

85. Dryzek, J.; Niemeyer, S. Discursive representation. Am. Political Sci. Rev. 2008, 102, 481-493. [CrossRef]

86. Kao, A.B.; Couzin, I.D. Decision accuracy in complex environments is often maximized by small group sizes. P. Roy. Soc. B Biol. Sci 2014, 218, 20133305. [CrossRef] [PubMed]

87. Nabatchi, T. Putting the "public" back in public values research: Designing participation to identify and respond to values. Public Adm. Rev. 2012, 72, 699-708. [CrossRef]

88. Gastil, J.; Rosenzweig, E.; Knobloch, K.R.; Brinker, D. Does the public want mini-publics? Voter responses to the Citizens' Initiative Review. Commun. Public 2016, 1, 174-192.

89. Smith, G. Democratic Innovations: Designing Institutions for Citizen Participation; Cambridge University Press: Cambridge, UK, 2009.

90. Dryzek, J.; Ercan, S.A.; Hendriks, C.M.; Niemeyer, S.; Manin, B.; Landemore, H.; Lupia, A.; Norton, A.; Shapiro, I.; Lafont, C. The prospects and limits of deliberative democracy. Daedalus 2017, 146, 6-84.

91. Gastil, J.; Richards, R.C. Deliberation. In International Encyclopedia of Political Communication; Mazzoleni, G., Ed.; John Wiley and Sons: Chichester, UK, 2016.

92. Curato, N.; Dryzek, J.S.; Ercan, S.A.; Hendriks, C.M.; Niemeyer, S. Twelve key findings in deliberative democracy research. Daedalus 2017, 146, 28-38. [CrossRef]

93. Pateman, C. Participatory democracy revisited. Perspect. Politics 2012, 10, 7-19. [CrossRef]

94. Ross, C. The Leaderless Revolution: How Ordinary People Will Take Power and Change Politics in the 21st Century; Simon and Schuster: London, UK, 2011.

95. Gilens, M.; Page, B.I. Testing theories of American politics: Elites, interest groups, and average citizens. Perspect. Politics 2014, 12, 564-581. [CrossRef]

96. Mackenzie, M.; Warren, M.E. Two trust-based uses of minipublics in democratic systems. In Deliberative Systems: Deliberative Democracy at the Large Scale. Theories of Institutional Design; Parkinson, J., Mansbridge, J., Eds.; Cambridge University Press: London, UK, 2012; pp. 95-124. 
97. McLaverty, P.; Halpin, D. Deliberative drift: The emergence of deliberation in the policy process. Int. Political Sci. Rev. 2008, 29, 197-214. [CrossRef]

98. Dryzek, J.S.; List, C. Social choice theory and deliberative democracy: A reconciliation. Br. J. Political Sci. 2003, 33, 1-28. [CrossRef]

99. Grönlund, K.; Setälä, M.; Herne, K. Deliberation and civic virtue: Lessons from a citizen deliberation experiment. Eur. Political Sci. Rev. 2010, 2, 95-117. [CrossRef]

100. Ryan, M.; Smith, G. Defining mini-publics. In Deliberative Mini-Publics: Involving Citizens in the Democratic Process; Grönlund, K., Bächtiger, A., Setälä, M., Eds.; ECPR Press: Colchester, UK, 2014; pp. 9-26.

101. Sandfort, J.; Quick, K. Deliberative technology: A holistic lens for interpreting resources and dynamics in deliberation. J. Public Delib. 2017, 13, 7.

102. Riedy, C.; Kent, J. Systemic Impacts of Mini-Publics; newDemocracy Foundation: Sydney, Australia, 2017; Available online: https:/newdemocracy.com.au/wpcontent/uploads/2017/06/docs_researchpapers_2017_ nDF_RP_20170613_SystemicImpactsOfMiniPublics.pdf (accessed on 28 August 2020).

103. Grönlund, K.; Herne, K.; Setälä, M. Does enclave deliberation polarize opinions? Political Behav. 2015, 37, 995. [CrossRef]

104. Luskin, R.C.; Fishkin, J.S.; Jowell, R. Considered opinions: Deliberative polling in Britain. Br. J. Political Sci. 2002, 32, 455-487. [CrossRef]

105. Dryzek, J.; Tucker, A. Deliberative innovation to different effect: Consensus conferences in Denmark, France, and the United States. Public Adm. Rev. 2008, 68, 864-876. [CrossRef]

106. Hendriks, C.; Dryzek, J.; Hunold, C. Turning up the heat: Partisanship in deliberative innovation. Political Stud. 2007, 55, 362-383. [CrossRef]

107. Weymouth, R.; Hartz-Karp, J. Deliberative collaborative governance as a democratic reform to resolve wicked problems and improve trust. J. Econ. Soc. Policy 2015, 17, 4.

108. Hartz-Karp, J.; Weymouth, R. Australian participatory budgeting. In Hope for Democracy: 30 Years of Participatory Budgeting Worldwide; Dias, N., Ed.; Epopeia Records: Faro, Portugal, 2018; pp. 403-422. Available online: https://www.oficina.org.pt/uploads/7/0/6/1/70619115/hope_for_democracy_-_digital.pdf (accessed on 28 August 2020).

109. Ebdon, C.; Franklin, A.L. Citizen participation in budgeting theory. Public Adm. Rev. 2006, 66, 437-447. [CrossRef]

110. Dias, N. The next thirty years of participatory budgeting in the world start today. In Hope for Democracy: 30 Years of Participatory Budgeting Worldwide; Epopeia Records: Faro, Portugal, 2018; Available online: https://www.oficina.org.pt/uploads/7/0/6/1/70619115/hope_for_democracy_-_digital.pdf (accessed on 28 August 2020).

111. Cabannes, Y.; Lipietz, B. Revisiting the democratic promise of participatory budgeting in light of competing political, good governance and technocratic logics. Environ. Urban. 2018, 30, 67-84. [CrossRef]

112. Thompson, N. Participatory budgeting-the Australian way. J. Public Delib. 2012, 8, 5.

113. Christensen, H.; Grant, B. Participatory budgeting in Australian local government: An initial assessment and critical issues. Aust. J. Public Adm. 2016, 75, 457-475. [CrossRef]

114. Parkinson, J. Hearing voices: Negotiating representation claims in public deliberation. Br. J. Politics Int. Relat. 2004, 6, 370-388. [CrossRef]

115. Cameron, S.M.; McAllister, I. Trends in Australian Political Opinion: Results from the Australian Election Study 1987-2016; School of Politics and International Relations, The Australian National University: Canberra, Australia, 2016.

116. Stoker, G.; Evans, M.; Halupka, M. Trust and Democracy in Australia: Democratic Decline and Renewal; Democracy 2025; 2018; Available online: https://apo.org.au/sites/default/files/resource-files/2018-12/apo-nid208536.pdf (accessed on 28 August 2020).

117. Foa, R.S.; Mounk, Y. The signs of deconsolidation. J. Democr. 2017, 28, 5-15. [CrossRef]

118. Ponce, A. Rule of Law Index 2014; World Justice Project: Washington, DC, USA, 2014.

119. Western Australian Local Government Association. Annual Community Perceptions Survey; Western Australian Local Government Association: Perth, Australia, 2014.

120. ABCNews. Council Quizzed over Rates Rise. Available online: http://www.abc.net.au/news/2012-09-12/ council-quizzed-over-rates-rise/4257308 (accessed on 28 August 2020). 
121. Dollery, B. Catalysing the Renewal of Local Infrastructure in Regional Communities: The Case for Local Infrastructure Australia; Regional Australia Institute, 2012; Available online: http://www.regionalaustralia.org.au/ wp-content/uploads/2013/06/RAI-Renewal-of-Local-Infrastructure-in-Regional-Australia.pdf (accessed on 28 August 2020).

122. City of Greater Geraldton. Climate of Opportunity: Community Survey and Deliberative Survey Report; City of Greater Geraldton: Geraldton, Australia, 2010.

123. Evans, M.; Stoker, G. Political participation in Australia: Contingency in the behaviour and attitudes of citizens. Aust. J. Political Sci. 2016, 51, 272-287. [CrossRef]

124. Wampler, B. Participatory budgeting: Core principles and key impacts. J. Public Delib. 2012, 8, 12. [CrossRef]

125. Allegretti, G. Paying attention to the participants' perceptions in order to trigger a virtuous circle. In Hope for Democracy: 25 Years of Participatory Budgeting Worldwide; Dias, N., Ed.; In loco Association: São Brás de Alportel, Portugal, 2014; pp. 47-63. Available online: https://eg.uc.pt/bitstream/10316/42326/1/PB\%20and\% 20the \%20budget \%20process\%20in\%20the\%20south\%20Kivu\%20Province.pdf (accessed on 28 August 2020).

126. Mansbridge, J.; Bohman, J.; Chambers, S.; Christiano, T.; Fung, A.; Parkinson, J.; Thompson, D.F.; Warren, M.E. A systemic approach to deliberative democracy. In Deliberative Systems: Deliberative Democracy at the Large Scale; Parkinson, J., Mansbridge, J., Eds.; Cambridge University Press: New York, NY, USA, 2012; pp. 1-26.

127. Lafont, C. Deliberation, participation, and democratic legitimacy: Should deliberative mini-publics shape public policy? J. Political Philos. 2015, 23, 40-63. [CrossRef]

128. PytlikZillig, L.; Tomkins, A.J.; Herian, M.N.; Hamm, J.A.; Abdel-Monem, T. Public input methods impacting confidence in government. Transform. Gov. People Process Policy 2012, 6, 92-111. [CrossRef]

129. Alves, M.L.; Allegretti, G. (In)stability, a key element to understand participatory budgeting: Discussing Portuguese cases. J. Public Delib. 2012, 8, 3.

130. Allegretti, G.; Hartz-Karp, J. Participatory budgeting: A methodological approach to address sustainability challenges. In Methods for Sustainability Research; Hartz-Karp, J., Marinova, D., Eds.; Edward Elgar: Cheltenham, UK, 2017.

131. Su, C. Managed participation: City agencies and micropolitics in participatory budgeting. Nonprofit Volunt. Sect. Q. 2018, 8, 1-21. [CrossRef]

132. City of Greater Geraldton. Participatory Budgeting Community Panel Range and Level of Services Final Report (9 April 2014); Curtin University and City of Greater Geraldton, 2014. Available online: https://www.cgg.wa.gov.au/Profiles/cgg/Assets/ClientData/Community_Panel_Range_and_Level_ Services_-_Participatory_Budgeting_Final_Report.pdf (accessed on 28 August 2020).

133. Hardin, R. Gaming trust. Trust and Reciprocity: Interdisciplinary Lessons from Experimental Research; Russell Sage Foundation: New York, NY, USA, 2003; pp. 80-101.

134. Trotsuk, I. "To Trust or Not to Trust" is not the question; "How to Study Trust" is much more challenging task. Russ. Sociol. Rev. 2016, 15, 57-75. [CrossRef]

135. Creswell, J. A Concise Introduction to Mixed Methods Research; SAGE: Thousand Oaks, CA, USA, 2014.

136. Möllering, G. The nature of trust: From Georg Simmel to a theory of expectation, interpretation and suspension. Sociology 2001, 35, 403-420. [CrossRef]

137. Cunliffe, A.L. On becoming a critically reflexive practitioner. J. Manag. Educ. 2004, 28, 407-426. [CrossRef]

138. Berner-Rodoreda, A.; Bärnighausen, T.; Kennedy, C.; Brinkmann, S.; Sarker, M.; Wikler, D.; Eyal, N.; McMahon, S.A. From doxastic to epistemic: A typology and critique of qualitative interview styles. Qual. Inq. 2018, 26, 291-305. [CrossRef]

139. Braun, V.; Clarke, V. Using thematic analysis in psychology. Qual. Res. Psychol. 2006, 3, 77-101. [CrossRef]

140. PytlikZillig, L.; Tomkins, A.; Herian, M.; Hoppe, R. Trust in government: Finding from public budgeting consultations. In Transatlantic Conference on Transparency Research; Utrech University: Utrech, The Netherlands, 7-9 June 2012.

141. Marien, S. The measurement equivalence of political trust. In Handbook on Political Trust; Edward Elgar Publishing: Cheltenham, UK, 2017; pp. 89-103.

142. Van Ryzin, G.G. The measurement of overall citizen satisfaction. Public Perform. Manag. Rev. 2004, $27,9-28$.

143. Fung, A. Varieties of participation in complex governance. Public Adm. Rev. 2006, 66, 66-75. [CrossRef]

144. Collins, K.; Ison, R. Jumping off Arnstein's ladder: Social learning as a new policy paradigm for climate change adaptation. Environ. Policy Gov. 2009, 19, 358-373. [CrossRef] 
145. Carson, L. The IAP2 Spectrum: Larry Susskind in conversation with IAP2 members. Int. J. Public Particip. 2008, 2, 67-84.

146. Carson, L.; Hartz-Karp, J. Adapting and combining deliberative designs. In The Deliberative Democracy Handbook: Strategies for Effective Civic Engagement in the Twenty-First Century; Gastil, J., Levine, P., Eds.; Jossey Bass: San Francisco, CA, USA, 2005; pp. 120-138.

147. Campbell, D.; Stanley, J. Experimental and Quasi-Experimental Designs for Research; Rand-McNally: Chicago, IL, USA, 1963.

148. City of Greater Geraldton. Particpatory Budgeting Community Panel 10 Year Capital Works Plan—Recommendations and Report to the City of Greater Geraldton (30 November 2013); Curtin University and City of Greater Geraldton, 2013; Available online: https://www.involve.org.uk/sites/default/files/field/attachemnt/Participatory_Budgeting_-_10_ Year_Capital_Works_Plan_Report_and_Recommendations_-_Final_-_Rated.pdf (accessed on 28 August 2020).

149. Cohen, J. Statistical Power Analysis for the Behavioral Sciences; Routledge: London, UK, 2013.

150. Weymouth, R.; Hartz-Karp, J. Principles for integrating the implementation of the Sustainable Development Goals in cities. Urban Sci. 2018, 2, 77. [CrossRef]

151. Jamieson, S. Likert scales: How to (ab)use them. Med Educ. 2004, 38, 1217-1218. [CrossRef] [PubMed]

152. Levitt, S.D.; List, J.A. Was there really a Hawthorne effect at the Hawthorne plant? An analysis of the original illumination experiments. Am. Econ. J. Appl. Econ. 2011, 3, 224-238. [CrossRef]

153. Stoker, G.; Hay, C.; Barr, M. Fast thinking: Implications for democratic politics. Eur. J. Political Res. 2016, 55, 3-21. [CrossRef]

154. US Census Bureau. QuickFacts_Lincoln city, Nebraska; US Census Bureau: Suitland, Suitland-Silver Hill, MD, USA, 2010.

155. PytlikZillig, L.; Abdel-Monem, T.; Herian, M.N.; Williams, D.T.; Tomkins, A.J. Taking Charge 2011: A Study of the 2011 Budgeting Priorities of the Residents of Lincoln, Nebraska; University of Nebraska Public Policy Centre: Lincoln, NE, USA, 2011.

156. Lind, E.A.; Van den Bos, K. When fairness works: Toward a general theory of uncertainty management. Res. Organ. Behav. 2002, 24, 181-223. [CrossRef]

157. Imbert, C.; Boyer-Kassem, T.; Chevrier, V.; Bourjot, C. Improving deliberations by reducing misrepresentation effects. Episteme 2019, 16, 1-17. Available online: https://poincare.univ-lorraine.fr/sites/poincare. univ-lorraine.fr/files/2019epistemeimbert_boyer_kassemimproving_deliberationsonline.pdf (accessed on 28 August 2020). [CrossRef]

158. Van Damme, J.; Brans, M. Managing public consultation: A conceptual framework and empirical findings from Belgian case studies. Public Adm. 2012, 90, 1047-1066. [CrossRef]

159. Head, B.W. Forty years of wicked problems literature: Forging closer links to policy studies. Policy Soc. 2019, 38, 180-197. [CrossRef]

160. Rittel, H.W.; Webber, M.M. Dilemmas in a general theory of planning. Policy Sci. 1973, 4, 155-169. [CrossRef]

161. UNDP. Governance for Sustainable Development: Integrating Governance in the Post-2015 Development Framework; United Nations Development Program: New York, NY, USA, 2014.

162. Varone, F.; Nahrath, S.; Aubin, D.; Gerber, J.-D. Functional regulatory spaces. Policy Sci. 2013, 46, 311-333. [CrossRef]

163. Van Bueren, E.M.; Klijn, E.H.; Koppenjan, J.F. Dealing with wicked problems in networks: Analyzing an environmental debate from a network perspective. J. Public Adm. Res. Theory 2003, 13, 193-212. [CrossRef]

164. Conklin, J. Dialogue Mapping: Building Shared Understanding of Wicked Problems; John Wiley and Sons: Hoboken, NJ, USA, 2005.

165. Weber, E.P.; Khademian, A.M. Wicked problems, knowledge challenges, and collaborative capacity builders in network settings. Public Adm. Rev. 2008, 68, 334-349. [CrossRef]

166. Cohen, B.; Winn, M.I. Market imperfections, opportunity and sustainable entrepreneurship. J. Bus. Ventur. 2007, 22, 29-49. [CrossRef]

167. UN. Transforming Our World: The 2030 Agenda for Sustainable Development; United Nations: New York, NY, USA, 2015.

168. Rozema, J.G.; Bond, A.J.; Cashmore, M.; Chilvers, J. An investigation of environmental and sustainability discourses associated with the substantive purposes of environmental assessment. Environ. Impact Assess. Rev. 2012, 33, 80-90. [CrossRef] 
169. Turnpenny, J.; Lorenzoni, I.; Jones, M. Noisy and definitely not normal: Responding to wicked issues in the environment, energy and health. Environ. Sci. Policy 2009, 12, 347-358. [CrossRef]

170. Kowarsch, M.; Garard, J.; Riousset, P.; Lenzi, D.; Dorsch, M.J.; Knopf, B.; Harrs, J.-A.; Edenhofer, O. Scientific assessments to facilitate deliberative policy learning. Nature 2016, 2, 1-20. [CrossRef]

171. McPhearson, T.; Parnell, S.; Simon, D.; Gaffney, O.; Elmqvist, T.; Bai, X.; Roberts, D.; Revi, A. Scientists must have a say in the future of cities. Nature News 2016, 538, 165. [CrossRef]

172. Gunnarsson-Östling, U.; Björnberg, K.E.; Finnveden, G. Using the concept of sustainability to work: Interpretations in academia, policy, and planning. In Sustainable Stockholm: Exploring Urban Sustainability in Europe's Greenest City; Metzger, J., Olsson, A.R., Eds.; Routledge: London, UK, 2013; pp. 51-70.

173. Stocker, L.; Burke, G. A new methodological framework for improving sustainability and climate change governance. In Methods for Sustainability Research; Hartz-Karp, J., Marinova, D., Eds.; Edward Elgar Publishing: Cheltenham, UK; Northampton, MA, USA, 2017; pp. 95-112.

174. Grint, K. Wicked problems and clumsy solutions: The role of leadership. Clin. Lead. 2008, 1, 54-68.

175. Pope, J.; Petrova, S. Sustainability assessment: A governance mechanism for sustainability. In Methods for Sustainability Research; Hartz-Karp, J., Marinova, D., Eds.; Edward Elgar Publishing: Cheltenham, UK; Northampton, MA, USA, 2017; pp. 142-156.

176. Sala, S.; Ciuffo, B.; Nijkamp, P. A systemic framework for sustainability assessment. Ecol. Econ. 2015, 119, 314-325. [CrossRef]

177. Lang, D.J.; Wiek, A.; Bergmann, M.; Stauffacher, M.; Martens, P.; Moll, P.; Swilling, M.; Thomas, C.J. Transdisciplinary research in sustainability science: Practice, principles, and challenges. Sustain. Sci. 2012, 7, 25-43. [CrossRef]

178. Meadowcroft, J. Who is in charge here? Governance for sustainable development in a complex world. J. Environ. Policy Plan. 2007, 9, 299-314. [CrossRef]

179. Joss, S. Danish consensus conferences as a model of participatory technology assessment: An impact study of consensus conferences on Danish Parliament and Danish public debate. Sci. Public Policy 1998, 25, 2-22.

180. Jensen, C.B. Citizen projects and consensus-building at the Danish Board of Technology: On experiments in democracy. Acta Sociol. 2005, 48, 221-235. [CrossRef]

181. Gastil, J.; Richards, R.C.; Knobloch, K.R. Vicarious deliberation: How the Oregon Citizens' Initiative Review influenced deliberation in mass elections. Int. J. Commun. 2014, 8, 62-89.

182. Knobloch, K.R.; Gastil, J.; Feller, T.; Richards, R.C. Empowering citizen deliberation in direct democratic elections: A field study of the 2012 Oregon Citizens' Initiative Review. Field Actions Science Reports (FACTS Reports). J. Field Actions 2014, 11, 1-10.

183. Cutler, F.; Johnston, R.; Carty, R.K.; Blais, A.; Fournier, P. Deliberation, information, and trust: The British Columbia Citizens' Assembly as agenda setter. In Designing Deliberative Democracy: The British Columbia Citizens' Assembly; Warren, M.E., Pearse, H., Eds.; Cambridge University Press: Cambridge, UK, 2008; pp. 166-191.

184. Jenke, E.; Lawson, E. Opinion is king: How governments can end the cycle of distrust. The Mandarin. 2016. Available online: https://www.themandarin.com.au/73172-opinion-king-governments-can-end-cycledistrust/ (accessed on 28 August 2020).

(C) 2020 by the authors. Licensee MDPI, Basel, Switzerland. This article is an open access article distributed under the terms and conditions of the Creative Commons Attribution (CC BY) license (http://creativecommons.org/licenses/by/4.0/). 